\title{
Penerapan Paikem untuk Meningkatkan Hasil Belajar IPA
}

\author{
I Made Bagiarta ${ }^{*}$ \\ ${ }^{1}$ SD Ngeri 7 Ban, Karangasem, Indonesia
}

\author{
A R T I C L E I N F O \\ Article history: \\ Received 19 February \\ 2021 \\ Received in revised form \\ 30 March 2021 \\ Accepted 10 April 2021 \\ Available online 11 May \\ 2021 \\ Kata Kunci: \\ PAIKEM dan Hasil Belajar \\ IPA. \\ Keywords: \\ PAIKEM and Science \\ Learning Outcomes.
}

\begin{abstract}
A B S T R A K
Rendahnya hasil belajar siswa dikarenakan minat siswa untuk belajar khususnya pada muatan pelajaran IPA masih kurang, sehingga diperlukan metode dan pendekatan pembelajaran yang kreatif untuk meningkatkan hasil belajar siswa. Tujuan penelitian ini adalah untuk menganalisis penerapan PAIKEM untuk meningkatkan Hasil blajar IPA pada siswa Kelas IV SD. Penelitian ini termasuk kedalam jenis penelitian tindakan kelas (PTK) yang dilakukan dalam 2 (dua) siklus. Subjek penelitian ini adalah siswa kelas IV SD yang berjumlah 11 orang dan objek penelitian ini adalah hasil belajar IPA. Data dikumpulkan dengan metode tes. Data yang terkumpul selanjutnya dianalisis dengan teknik analisis ststistik deskriptif kuantitatif. Hasil penelitian menunjukkan bahwa perolehan nilai rata-rata hasil belajar pada refleksi awal sebesar 65,91, menjadi 70,45 pada siklus I dan pada siklus II mengalami peningkatan sebesar 5,91 menjadi 76,36. Simpulan penelitian ini adalah penerapan PAIKEM dapat meningkatkan hasil belajar IPA siswa kelas IV SD.
\end{abstract} Implikasi penelitian ini adalah penerapan pendekatan pembelajaran PAIKEM dapat memotivasi siswa untuk mengikuti kegiatan pembelajaran, membuat siswa terlibat secara aktif, melatih kemampuan komunikasi dan interaksi yang dimiliki oleh siswa.

\begin{abstract}
A B S T R A K
The low student learning outcomes are due to the lack of student interest in learning, especially in science subject content, so that creative learning methods and approaches are needed to improve student learning outcomes. The purpose of this study was to analyze the application of PAIKEM to improve Science learning outcomes in grade IV SD students. This research belongs to the type of classroom action research (PTK) which was conducted in 2 (two) cycles. The subjects of this study were 11 grade students of $S D$, and the object of this research was the science learning outcomes. The data were collected by using the test method. The collected data were then analyzed using quantitative descriptive statistical analysis techniques. The results showed that the average value of learning outcomes at the initial reflection was 65.91 to 70.45 in the first cycle and in the second cycle increased by 5.91 to 76.36. The conclusion of this research is that the application of PAIKEM can improve the learning outcomes of fourth grade students of elementary school science. The implication of this research is that the application of the PAIKEM learning approach can motivate students to take part in learning activities, make students actively involved, train their communication and interaction skills.
\end{abstract}

\section{Pendahuluan}

Pendidikan merupakan sebuah proses yang dialami oleh setiap orang. Pendidikan ini memiliki fungsi untuk mengembangkan kemampuan dan membentuk watak serta peradaban bangsa yang bermartabat dalam rangka mencerdaskan kehidupan bangsa, bertujuan untuk berkembangnya potensi peserta didik agar menjadi manusia yang berkarakter yang baik serta mampu mengimplementasikan potensi diri didalam kehidupan sehari-hari (Amelia \& Saputra, 2017; Kristiantari, 2015; Shafa, 2014). 
Sebagai kader masa depan bangsa memiliki kewajiban tersendiri untuk mengembangkan potensi diri dengan membekali berbagai pengetahuan. Pengetahuan dan wawasan sangat menentukan kualitas kompetensi sumber daya manusia itu sendiri. Pergeseran zaman dengan berbagai iklim kehidupan yang beragam menuntut perkembangan sumber daya manusia yang bermutu. Salah satu upaya yang ditempuh untuk meningkatkan mutu sumber daya manusia adalah melalui pendidikan, dengan demikian keberadaan pendidikan memiliki andil yang cukup besar (Irawan, 2016; Resbiantoro, 2016; Suparlan, 2017).

Proses pendidikan dapat berlangsung pada suatu institusi atau lembaga pendidikan tertentu yang bersifat formal maupun non formal (Kurniaman \& Noviana, 2017b; Subadi et al., 2013; W Wahyudin, 2018). Berkaitan dengan pendidikan formal, maka peran guru sangat menonjol dalam pembelajaran. Suksesnya sebuah pembelajaran tidak terlepas dari dua faktor utama yaitu peran pendidik dan peserta didik. Bagaimana pendidik mengajar dan bagaimana peserta didik belajar merupakan dua hal mendasar dalam sebuah pembelajaran. Keberhasilan sebuah pembelajaran akan tergambar dengan adanya perubahan tingkah laku yang menyangkut pengetahuan, sikap dan keterampilan. Perubahan dalam aspekaspek tersebut merupakan hasil belajar atau produk akhir sebuah pembelajaran. Oleh karena itu, untuk mencapai hasil belajar yang baik, maka kualitas kegiatan pembelajaran juga perlu ditingkatkan.

Berbicara tentang pendidikan tidak dapat dilepaskan dengan kegiatan pembelajaran. Pembelajaran merupakan sebuah proses belajar yang perlu mendapatkan perhatian secara serius, proses pembelajaran ini akan dapat berlangsung dengan baik apabila komponen-komponen yang terlibat di dalamnya saling mendukung dan melengkapi (Mulyadin, 2016; Susilo et al., 2018; Sutrisno, 2015). Banyak faktor yang berpengaruh terhadap kelancaran proses pembelajaran. (Kurniaman \& Noviana, 2017a; Sutrisno, 2015; Wahyudin Wahyudin, 2018), menyatakan bahwa faktor-faktor yang mempengaruhi belajar adalah faktor eksternal dan internal. Faktor eksternal (luar) merupakan faktor lingkungan peserta didik dan faktor instrumental, sedangkan faktor internal (dalam) meliputi kecerdasan, bakat, minat, motivasi, dan kemampuan kognitif. Selain itu kedua faktor tersebut saling berhubungan dan dapat berpengaruh dalam motivasi kemampuan belajar serta intelegensi yang dimiliki oleh siswa.

Banyak faktor yang berpengaruh terhadap hasil belajar, baik yang bersifat internal maupun eksternal. Pemerintah yang memiliki kewenangan atau yang berkecimpung dalam dunia pendidikan terus mengambil langkah pembaharuan dan pembenahan di berbagai aspek pendidikan dalam rangka mencapai hasil belajar yang baik yang berujung pada kualitas sumber daya manusia yang berkompeten dan handal. Pengembangan langkah pemerintah bukan semata-mata hanya dalam pembelajaran saja tetapi juga meningkatkan kualitas guru sebagai organisator pembelajaran. Peningkatan kualitas guru ditempuh dengan cara melibatkat guru melalui kegiatan seperti memberikan penataran terhadap guru-guru, mengadakan seminar, workshop dan meningkatkan pendidikan guru melalui program-program penyetaraan atau pemberian beasiswa (Darmadi, 2015; Hafriani, 2019; Parida, 2015). Di samping itu, dalam proses pembelajaran banyak perubahan yang dilakukan seperti menggunakan berbagai pendekatan pembelajaran yang inovatif, upaya-upaya yang telah ditempuh tersebut belum sepenuhnya memberikan peningkatan hasil maupun motivasi terhadap siswa secara signifikan. Pemerintah tidak berhenti sampai di sana, perubahan-perubahan terus dilakukan baik terhadap kurikulum maupun strategi pembelajaran agar hasil belajar dapat dicapai secara maksimal. Berbagai kendala yang ditemukan di lapangan dijadikan sebagai bahan kajian yang selanjutnya dicarikan solusi sebagai langkah alternatif.

Kesenjangan di lapangan sering mengarahkan berbagai pihak untuk berusaha secara maksimal mengantisipasi permasalahan yang muncul. Demikian juga halnya yang terjadi di SD Negeri 7 Ban. Permasalahan pembelajaran cukup kompleks. Hasil observasi menunjukkan bahwa minat siswa terhadap pembelajaran IPA masih kurang karena mata pelajaran ini dipandang bersifat kompleks sehingga sulit dipahami, motivasi siswa untuk belajar IPA masih kurang, rata-rata hasil belajar pendidikan IPA rendah, secara personal masih terdapat siswa yang memiliki hasil belajar di bawah Kriteria Ketuntasan Minimal (KKM) yang ditetapkan, siswa sering pasif dalam mengikuti proses pembelajaran seperti, kurangnya perhatian pada materi yang diajarkan, kurangnya kesadaran untuk belajar mandiri, belajar dijadikan sebagai beban dan suatu kewajiban semata bukan sebagai kebutuhan, kurangnya usaha untuk memproleh pengetahuan tambahan yang berkaitan dengan materi yang diajarkan, kurangnya perhatian dan motivasi siswa terhadap hal-hal yang terpendam dalam materi pembelajaran dan kurangnya keterlibatan siswa dalam pembelajaran dalam memanfaatkan lingkungan, kurangnya kesadaran siswa untuk memanfaatkan waktu senggang di luar jam pelajaran untuk menanyakan sesuatu yang kurang dimengerti.

Untuk itu sebagai salah satu komponen yang sangat penting dalam meningkatkan kualitas pendidikan, kegiatan belajar mengajar perlu dirancang agar mampu meningkatkan pemahaman konsep siswa serta sejalan dengan tuntutan Kurikulum Tingkat Satuan Pendidikan (KTSP). Reformasi pendidikan dalam kaitannya dengan kegiatan belajar mengajar setidaknya dimulai dari bagaimana siswa belajar dan bagaimana guru mengajar, bukan semata-mata fokus pada hasil belajar. Hal ini didukung oleh pendapat 
(Makaborang, 2019; Morelent \& Syofiani, 2018; Prasetyo et al., 2016) yang menyatakan bahwa salah satu faktor utama sebagai pengahalang terciptanya pemahaman pada diri siswa adalah substansi kurikulum yang cenderung dekontektual. Oleh karena itu, sangat diperlukan suatu pembelajaran yang memiliki paradigma sejalan dengan Kurikulum Tingkat Satuan Pendidikan (KTSP) agar mampu mengembangkan kemampuan berpikir kritis siswa sehingga pemahaman siswa terhadap pembelajaran IPA dapat terbentuk dengan baik dan benar serta dalam suasana yang menyenangkan bagi siswa. Situasi belajar yang menarik pada umumnya dapat memotivasi siswa dan mendorong minat siswa untuk mengikuti kegiatan pembelajaran.

Proses pembelajaran memerlukan menejemen yang efektif agar memperoleh hasil yang memuaskan, maka pendidik harus mengelola pembelajaran yang efektif dengan ditunjang oleh penggunaan media pembelajaran dan pemilihan strategi pembelajaran yang tepat. Dalam Kurikulum Pendidikan Dasar pada pengembangan keterampilan baca, tulis, dan hitung mencerminkan bahwa materi pembelajaran IPA sangat penting terutama dalam hal pembentukan kemampuan berpikir siswa yang sistematis dan analitis yang dibuktikan dengan hasil belajar siswa (Pamungkas et al., 2017; Safitri, S. R., \& Budhi, 2017; Wardani et al., 2015). Untuk mencapai hasil yang maksimal memerlukan pengelolaan pembelajaran yang efektif serta menejemen kelas yang efesien. Dengan demikian seorang pendidik memerlukan pemilihan strategi pembelajaran yang baik. Guru sebagai pengajar kreatif dalam upaya menggali, menemukan atau menciptakan gagasan berupa metode pembelajaran yang inovatif (Aryani, 2014; Hayati \& Lailatussaadah, 2016; Rahmawati et al., 2014). Berangkat dari hal tersebut, maka dipilih sebuah pendekatan pembelajaran yang disebut dengan PAIKEM. PAIKEM merupakan pendekatan pembelajaran yang memiliki arti Pembelajaran Aktif, Inovatif, Kreatif, Efektif dan Menyenangkan (Adibatin, 2016; Aryani, 2014; Hayati \& Lailatussaadah, 2016). Penerapan pendekatan PAIKEM ini diharapkan permasalahan yang dialami oleh guru maupun siswa dalam pembelajaran dapat diatasi dan membuat pembelajaran yang dilaksanakan lebih bermakna bagi siswa. Kelebihan penerapan PAIKEM sebagai berikut: (1) membantu siswa terlibat secara aktif baik fisik, mental maupun emosional, (2) kegiatan pembelajaran memungkinkan terjadinya komunikasi antara guru dan peserta didik, (3) kegiatan pembelajaran memungkinkan terjadinya interaksi multi arah, (4) kegiatan pembelajaran yang memungkinkan peserta didik memikirkan kembali apa yang telah dilakukan (Hayati \& Lailatussaadah, 2016; Rahmawati et al., 2014; Sulthon, 2016).

Penelitian ini didukung dengan penelitian sebelumnya yang dianggap relevan dengan penelitian ini, seperti: (1) penelitian yang dilaksanakan oleh (Sabihi, 2019), yang memperoleh hasil yaitu penerapan PAIKEM Gembrot dapat meningkatkan hasil belajar IPA siswa; (2) penelitian yang dilaksanakan oleh (Suryaningsih, 2016), yang memperoleh hasil yaitu penerapkan model reading guide berbasis PAIKEM dapat meningkatkan motivasi belajar siswa; (3) penelitian yang dilaksanakan oleh (Khairani, 2015), yang memperoleh hasil yaitu pembelajaran PAIKEM dapat meningkatkan motivasi belajar siswa.

Tujuan penelitian ini adalah untuk menganalisis penerapan PAIKEM untuk meningkatkan hasil belajar IPA siswa kelas IV Semester I Tahun Pelajaran 2018/2019 di SD Negeri 7 Ban, Kecamatan Kubu, Kabupaten Karangasem.

\section{Metode}

Penelitian Tindakan Kelas (PTK) merupakan penelitian tentang situasi kelas yang dilakukan secara sistematis dengan mengikuti prosedur tertentu. Penelitian ini dilakukan dari bulan Agustus sampai bulan Desember 2018. Penelitian Tindakan Kelas (PTK) ini dilakukan dalam dua siklus yang msingmasing siklus terdiri dari empat tahapan yaitu perencanaan, pelaksanaan tindakan, observasi-evaluasi, dan refleksi. Rancangan penelitian ini bertujuan untuk mendeskripsikan adanya peningkatan hasil belajar dengan penerapan PAIKEM dalam pembelajaran siswa kelas IV Semester I Tahun Pelajaran 2018/2019 di SD Negeri 7 Ban, Kecamatan Kubu, Kabupaten Karangasem.

Subjek penelitian dalam Penelitian Tindakan Kelas ini adalah siswa kelas IV SD Negeri 7 Ban Kecamatan Kubu Kabupten Karangasem semester I tahun pelajaran 2018/2019 yang berjumlah 11 orang. Dari jumlah siswa tersebut terdapat 7 orang siswa laki-laki dan 4 orang siswa perempuan. Objek penelitian ini adalah hasil belajar IPA siswa kelas IV SD Negeri 7 Ban semester I tahun pelajaran 2018/2019 dengan rentang waktu sekitar lima bulan. Semua bentuk tindakan yang dilakukan mengacu pada tahapan-tahapan siklus yang telah direncanakan.

Teknik pengumpulan data yang dipakai dalam penelitian adalah dengan menggunakan Tes. Tes yang dimaksudkan dalam penelitian ini adalah seperangkat tes tertulis yang berbentuk soal pilihan ganda. Tes ini diberikan sebagai evaluasi terhadap pelaksanaan masing-masing siklus. Instrumen penelitian yang digunakan adalah soal pilihan ganda dengan jumlah sebanyak 20 butir. Bobot masing-masing butir adalah 1. Skor maksimal ideal (SMI) dari seluruh soal yang digunakan adalah 20 dan skor minimalnya adalah 0 . 
Data hasil belajar siswa yang terkumpul pada siklus I dan siklus II diolah dengan menggunakan tes hasil belajar. Data hasil belajar IPA dianalisis secara deskriptif kuantitatif melalui penentuan nilai ratarata hasil belajar.

\section{Hasil dan Pembahasan}

Kondisi awal dari siswa kelas IV SD Negeri 7 Ban semester I Tahun Pelajaran 2018/2019 secara klasikal siswa kelas IV SD Negeri 7 Ban sementer I pada tahun pelajaran 2018/2019 belum mencapai Kriteria Ketuntasan Minimal (KKM) IPA yang ditetapkan pihak sekolah. Refleksi awal menunjukkan bahwa nilai rata-rata klasikal hanya mampu tercapai 65,91 dari 70 yang ditargetkan dalam KKM. Begitu juga dengan ketuntasan belajar klasikal masih tergolong rendah karena hanya mampu mencapai 36,36\% dari 75\% yang ditargetkan. Data hasil belajar repleksi awal tersebut dapat disajikan pada Gambar 1.

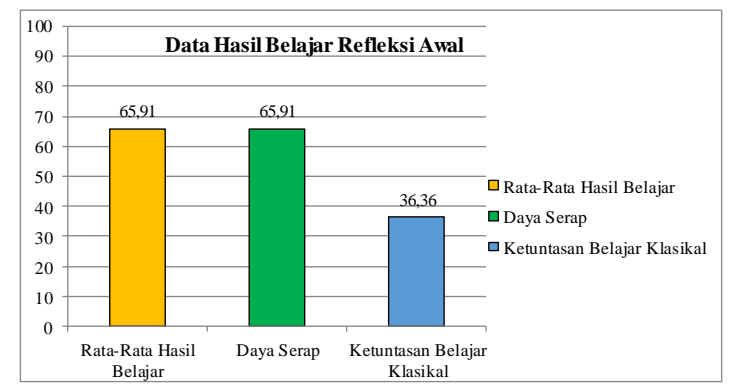

Gambar 1. Grafik Batang Data Hasil Belajar Refleksi Awal

Capaian hasil seperti tersebut di atas disebabkan oleh pola pembelajaran yang masih didominasi oleh guru serta metode yang digunakan lebih banyak menggunakan metode ceramah. Hal ini cenderung membuat kondisi belajar menjadi pasif, interaksi kurang sehingga memicu suasana belajar yang kurang menarik. Memperhatikan kendala yang dihadapi dalam pembelajaran tersebut, maka guru mencari solusi sebagai langkah terobosan mengatasi permasalahan tersebut. Tujuannya adalah untuk menciptakan pembelajaran yang menarik, aktif, menyenangkan sehingga berujung pada tercapainya target minimal sesuai dengan KKM dan ketuntasan belajar yang ditetapkan. Oleh karena itu, diterapkan PAIKEM untuk meningkatkan Hasil Belajar IPA bagi Siswa Kelas IV SD Negeri 7 Ban semester I tahun pelajaran $2018 / 2019$.

Hasil Siklus I berpedoman pada hasil belajar dan hasil refleksi awal yang dilaksanakan, maka sebagai langkah terobosan dilaksanakan tindakan siklus I melalui penerapan PAIKEM. Hasil belajar IPA siswa kelas IV SD Negeri 7 Ban Ssemester I siklus I disajikan dalam Tabel 1.

Tabel 1. Hasil Belajar IPA Siswa Kelas IV SD Negeri 7 Ban Siklus I

\begin{tabular}{lccc}
\hline \multicolumn{1}{c}{ NAMA SISWA } & NIS & NILAI & KETERANGAN \\
\hline I Kadek Suarka Ardika & 590 & 65 & Belum Tuntas \\
Ni Kadek Swami & 591 & 60 & Belum Tuntas \\
I Ketut Aditya Kumara & 595 & 75 & Tuntas \\
Ni Kadek Ayu Apriliani & 596 & 80 & Tuntas \\
I Wayan Budiarta & 597 & 80 & Tuntas \\
I Made Eka Aditya & 598 & 75 & Tuntas \\
Ni Komang Dewi Lestari & 599 & 70 & Tuntas \\
Ni Kadek Lia April & 600 & 75 & Tuntas \\
I Komang Swardaya & 601 & 65 & BelumTuntas \\
I Komang Timi Rahadi & 602 & 65 & BelumTuntas \\
I Kadek Asta Dana & 636 & 65 & BelumTuntas \\
\hline Jumlah & & $\mathbf{7 7 5}$ & \\
\hline Nilai rata-rata & & $\mathbf{7 0 . 4 5}$ & \\
\hline Daya Serap & & $\mathbf{7 0 . 4 5}$ & \\
\hline Ketuntasan Klasikal & & $\mathbf{5 4 5}$ & \\
\hline
\end{tabular}

Berdasarkan hasil analisis dalam Tabel 1, diketahui bahwa secara klasikal siswa kelas IV SD Negeri 7 Ban semester I tahun pelajaran 2018/2019 sudah mampu mencapai target KKM yang ditetapkan pada mata pelajaran IPA. Rata-rata hasil belajar klasikal pada siklus I sebesar 70,45. Ini menunjukkan 
bahwa hasil tersebut telah sesuai dengan KKM yang besarnya juga 70 bahkan melampaui target meskipun dengan selisih yang kecil yaitu 0,45 . Pada sisi yang lainnya target ketuntasan belajar secara klasikal belum sesuai dengan harapan yaitu 75\%, target baru tercapai sebesar 54,55\% yang ditunjukkan dengan jumlah siswa yang tuntas sebanyak 6 orang dan belum tuntas sebanyak 5 orang. Data Hasil Belajar Refleksi Siklus I tersebut dapat disajikan pada Gambar 2.

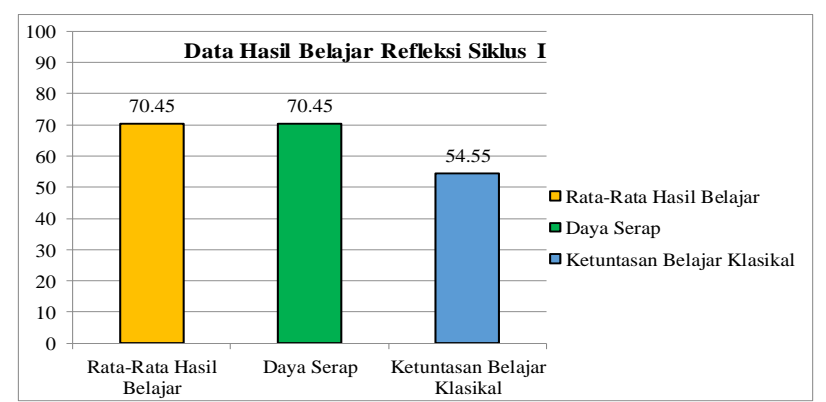

Gambar 2. Grafik Batang Data Hasil Belajar Refleksi Siklus I

Mengkaji hasil dari pelaksanaan siklus I, maka diketahui bahwa pelaksanaan siklus I memiliki beberapa kelemahan. Kelemahan ini akan dicermati dan akan dijadikan sebagai bahan pertimbangan dalam pebaikan pada siklus berikutnya yaitu siklus II. Beberapa kelemahan yang ditemukan sebagai hasil refleksi siklus I adalah: 1) Keaktifan siswa masih kurang, 2) Fokus perhatian siswa masih terbagi dan terbawa model desain pembelajaran lama, 3) Pembelajaran kurang didukung media yang cukup sehingga transfer pengetahuan tentang materi tertentu membuat siswa hanya bisa membayangkan saja tanpa ada media tertentu yang dapat menggambarkan masalah tersebut, 4) Kreativitas siswa belum muncul secara maksimal, siswa cenderung menunggu sesuatu yang dikerjakan (kurang mandiri). Semua permasalahan yang ditemukan dalam siklus I selanjutnya dicermati dan dilakukan tindakan perbaikan pada siklus II. Adapun perbaikan-perbaikan tersebut adalah sebagai berikut: 1) Siswa dikondisikan agar keterlibatannya maksimal dalam pembelajaran sehingga keaktifannya meningkat, 2) Siswa dimotivasi agar tetap semangat dan disiplin dalam pembelajaran, 3) Menciptakan kondisi pembelajaran di kelas yang menarik dan menyenangkan lebih banyak berinovasi dalam pembelajaran, 4) Penggunaan media yang relevan dan memfasilitasi penggunaan media sehingga pembelajaran menjadi lebih aktif dan menarik, 5) Guru menyiapkan desain pembelajaran yang lebih menarik dengan membuat LKS sehingga siswa terkondisi untuk aktif dan kreatif, 6) Memberikan kesempatan kepada siswa untuk memanfaatkan waktunya lebih banyak dengan berbagi pengalaman atau pengetahuan dengan teman dalam kegiatan diskusi sehingga secara keseluruhan siswa akan aktif.

Berdasarkan hasil belajar dan refleksi yang dilaksanakan pada siklus I, maka dilakukan tindakan siklus II yang merupakan sebuah kegiatan perbaikan terhadap pelaksanaan pembelajaran siklus I. Hasil belajar IPA siswa kelas IV SD Negeri 7 Ban semester I tahun pelajaran 2018/2019 siklus II disajikan dalam Tabel 2.

Tabel 2. Hasil Belajar IPA Siswa Kelas IV SD Negeri 7 Ban Siklus II

\begin{tabular}{lccc}
\hline \multicolumn{1}{c}{ NAMA SISWA } & NIS & NILAI & KETERANGAN \\
\hline I Kadek Suarka Ardika & 590 & 75 & Tuntas \\
Ni Kadek Swami & 591 & 70 & Tuntas \\
I Ketut Aditya Kumara & 595 & 75 & Tuntas \\
Ni Kadek Ayu Apriliani & 596 & 85 & Tuntas \\
I Wayan Budiarta & 597 & 85 & Tuntas \\
I Made Eka Aditya & 598 & 80 & Tuntas \\
Ni Komang Dewi Lestari & 599 & 70 & Tuntas \\
Ni Kadek Lia April & 600 & 80 & Tuntas \\
I Komang Swardaya & 601 & 75 & Tuntas \\
I Komang Timi Rahadi & 602 & 75 & Tuntas \\
I Kadek Asta Dana & 636 & 70 & Tuntas \\
\hline Jumlah & & $\mathbf{8 4 0}$ & \\
\hline Nilai rata-rata & $\mathbf{7 6 . 3 6}$ & \\
\hline Daya Serap & $\mathbf{7 6 . 3 6 \%}$ & $\mathbf{1 0 0 \%}$ \\
\hline Ketuntasan Klasikal & &
\end{tabular}


Hasil analisis menunjukkan bahwa secara klasikal rata-rata hasil belajar siswa kelas IV SD Negeri 7 Ban semester I pada tahun pelajaran 2018/2019 telah mencapai Kriteria Ketuntasan Minimal (KKM) yang ditetapkan oleh sekolah dalam bidang mata pelajaran IPA. Hal ini dibuktikan dengan capaian nilai rata-rata hasil belajar klasikal sebesar 76,36 pada siklus II. Ini juga menandakan bahwa target sesuai KKM terlampaui. Demikian juga pada siklus II ini ketuntasan klasikal telah tercapai bahkan dapat melampaui target yaitu sebesar 100\% dari target 75\% yang ditetapkan. Data Hasil Belajar Refleksi Siklus II tersebut dapat disajikan pada Gambar 3.

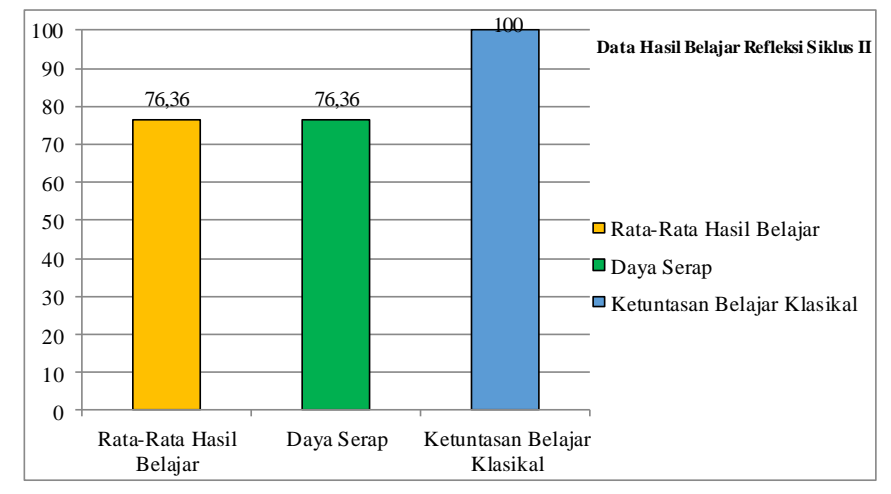

Gambar 3. Grafik Batang Data Hasil Belajar Refleksi Siklus II

Tindakan yang dilakukan pada siklus II merupakan penyempurnaan terhadap tindakan pada siklus I. Hal mendasar yang membedakan antara siklus I dengan siklus II adalah adanya bimbingan yang dilakukan dalam siklus II sebagai upaya untuk meningkatkan atau memaksimalkan keterlibatan siswa dalam pembelajaran. Beberapa temuan dalam pelaksanaan tindakan di siklus II antara lain: 1) Secara bertahap motivasi siswa sudah semakin tumbuh sehingga menjadi dasar kesadaran terhadap perannya dalam pembelajaran, 2) Siswa semakin terfokus terhadap pembelajaran degan mencermati dan keterlibatannya dalam setiap langkah yang dilakukan guru dalam pembelajaran, 3) Desain pembelajaran yang menarik dan penggunaan media yang relevan meningkatkan peran dan keatifan siswa, 4) Krea tivitas siswa telah tampak dengan keterlibatannya secara maksimal dalam aktivitas pembelajaran.

Mengacu pada hasil analisis yang dilakukan pada setiap tahapan yang dilaksanakan, maka dapat ditegaskan bahwa penerapan PAIKEM dapat meningkatkan hasil belajar IPA siswa kelas IV SD Negeri 7 Ban semester I tahun pelajaran 2018/2019. Peningkatan hasil belajar siswa kelas IV SD Negeri 7 Ban tersebut tergambar dari nilai rata-rata, daya serap, dan ketuntasan belajar klasikal yang diperoleh. Rekapitulasi terhadap keseluruhan nilai tersebut dapat disajikan dalam Tabel 3.

Tabel 3. Rekapitulasi Data Hasil Belajar, Daya Serap, dan Ketuntasan Belajar Klasikal IPA Siswa Kelas IV SD Negeri 7 Ban

\begin{tabular}{cclcc}
\hline No & Jenis Rekapitulasi Data & \multicolumn{1}{c}{ Tahapan } & Nilai & Peningkatan \\
\hline \multirow{2}{*}{ Rata-rata Hasil Belajar } & Refleksi Awal & 65,91 & \\
& & Siklus I & 70,45 & 4,54 \\
\multirow{2}{*}{2} & \multirow{2}{*}{ Daya Serap } & Siklus II & 76,36 & 5,91 \\
& & Refleksi Awal & $65,91 \%$ & \\
& & Siklus I & $70,45 \%$ & $4,54 \%$ \\
3 & \multirow{2}{*}{ Ketuntasan Belajar Klasikal } & Siklus II & $76,36 \%$ & $5,91 \%$ \\
& & Refleksi Awal & $36,36 \%$ & $18,19 \%$ \\
& & Siklus I & $54,55 \%$ & $45,45 \%$ \\
\hline
\end{tabular}

Berdasarkan Tabel 3, rekapitulasi tersebut, maka dapat digambarkan bahwa hasil belajar IPA siwa kelas IV SD Negeri 7 Ban semester I tahun pelajaran 2018/2019 mengalami peningkatan baik dari refleksi awal, siklus I hingga siklus II. Peningkatan ini dapat dilihat dari nilai rata-rata hasil belajar yaitu pada refleksi awal sebesar 65,91 (tergolong belum tuntas) menjadi 70,45 pada siklus I (tegolong tuntas) dengan peningkatan sebesar 4,54. Sedangkan pada siklus II mengalami peningkatan sebesar 5,91 menjadi 76,36 (tergolong tuntas). Data tersebut dapat disajikan pada Gambar 4. 


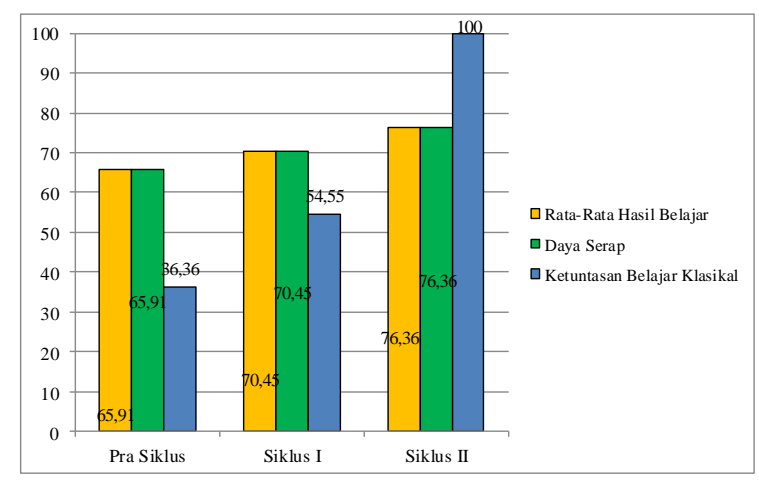

Gambar 4. Grafik Batang Rekapitulasi Hasil Belajar Refleksi Awal, Siklus I dan Siklus II

Di samping peningkatan pada hasil belajar, peningkatan juga terjadi pada daya serap dan ketuntasan belajar klasikal. Pada refleksi awal daya serap tercapai sebesar $65,91 \%$ selanjutnya pada siklus I meningkat menjadi 70,45\%. Hal yang sama juga terjadi pada siklus II dengan daya serap mencapai 76,36\%. Sedangkan ketuntasan belajar klasikal pada refleksi awal sebesar 36,36\% kemudian meningkat menjadi $54,55 \%$ pada siklus I dan menjadi $100 \%$ pada siklus II. Peningkatan ini disebabkan penggunaan pendekatan PAIKEM yang efektif diterapkan. PAIKEM merupakan pendekatan pembelajaran yang memiliki arti Pembelajaran Aktif, Inovatif, Kreatif, Efektif dan Menyenangkan (Adibatin, 2016; Aryani, 2014; Hayati \& Lailatussaadah, 2016). Penerapan pendekatan PAIKEM ini diharapkan permasalahan yang dialami oleh guru maupun siswa dalam pembelajaran dapat diatasi dan membuat pembelajaran yang dilaksanakan lebih bermakna bagi siswa. Kelebihan penerapan PAIKEM sebagai berikut: (1) membantu siswa terlibat secara aktif baik fisik, mental maupun emosional, (2) kegiatan pembelajaran memungkinkan terjadinya komunikasi antara guru dan peserta didik, (3) kegiatan pembelajaran memungkinkan terjadinya interaksi multi arah, (4) kegiatan pembelajaran yang memungkinkan peserta didik memikirkan kembali apa yang telah dilakukan (Hayati \& Lailatussaadah, 2016; Rahmawati et al., 2014; Sulthon, 2016).

Penelitian ini didukung dengan penelitian sebelumnya yang dianggap relevan dengan penelitian ini, seperti: (1) penelitian yang dilaksanakan oleh (Sabihi, 2019), yang memperoleh hasil yaitu penerapan PAIKEM Gembrot dapat meningkatkan hasil belajar IPA siswa; (2) penelitian yang dilaksanakan oleh (Suryaningsih, 2016), yang memperoleh hasil yaitu penerapkan model reading guide berbasis PAIKEM dapat meningkatkan motivasi belajar siswa; (3) penelitian yang dilaksanakan oleh (Khairani, 2015), yang memperoleh hasil yaitu pembelajaran PAIKEM dapat meningkatkan motivasi belajar siswa.

Implikasi penelitian ini adalah penerapan pendekatan pembelajaran PAIKEM dapat memotivasi siswa untuk mengikuti kegiatan pembelajaran, membuat siswa terlibat secara aktif, melatih kemampuan komunikasi dan interaksi yang dimiliki oleh siswa.

\section{Simpulan}

Berdasarkan hasil penelitian yang diuraikan dalam Bab IV, maka dapat disimpulkan bahwa penerapan PAIKEM dapat meningkatkan hasil belajar siswa kelas IV SD Negeri 7 Ban semester I tahun pelajaran 2018/2019. Implikasi penelitian ini adalah penerapan pendekatan pembelajaran PAIKEM dapat memotivasi siswa untuk mengikuti kegiatan pembelajaran, membuat siswa terlibat secara aktif, melatih kemampuan komunikasi dan interaksi yang dimiliki oleh siswa.

\section{Daftar Rujukan}

Adibatin, A. (2016). Pendidikan Karakter Bangsa Berbasis Strategi Pembelajaran PAKEM Melalui Permainan Cincin Di Jempol Tangan (Karya Inovasi Pembelajaran Sekolah Dasar). Scholaria: Jurnal Pendidikan Dan Kebudayaan, 6(1), 18 - 18. https://doi.org/10.24246/j.scholaria.2016.v6.i1.p1-18

Amelia, D. J., \& Saputra, S. Y. (2017). Analisis Kelayakan Buku Siswa Kelas IV Tema Makhluk Hidup Kurikulum 2013. Pedagogia: Jurnal Pendidikan, 6(1), 98-109. https://doi.org/10.21070/pedagogia.v6i1.617

Aryani, W. D. (2014). Peningkatan Keaktifan Dan Hasil Belajar IPS Melalui Pakem Dengan Bantuan Media Pada Siswa Kelas VIIIA SMP Negeri 1 Kandeman Batang Tahun Pelajaran 2013/2014. Forum Ilmu 
Sosial, 41(1), 103-124. https://doi.org/10.15294/fis.v41i1.5397

Darmadi, H. (2015). Tugas, Peran,Kompetensi, dan Tanggung Jawab Menjadi Guru Profesional. Jurnal Edukasi, 13(2). https://doi.org/10.31571/edukasi.v13i2.113

Hafriani. (2019). Analisis Kompetensi Profesional Guru Matematika Bersertifikat Pendidik Pada Madrasah Ibtidaiyah Negeri Di Kabupaten Aceh Barat. Jurnal Ilmiah Didaktika, 20(1), 58-68. https://doi.org/10.22373/jid.v20i1.3856

Hayati, S., \& Lailatussaadah. (2016). Validitas Dan Reliabilitas Instrumen Pengetahuan Pembelajaran Aktif, Kreatif Dan Menyenangkan (Pakem) Menggunakan Model Rasch. Jurnal Ilmiah Didaktika, 16(2), 169-179. https://doi.org/10.22373/jid.v16i2.593

Irawan, E. (2016). Implementasi Penanaman Karakter Melalui Matematika Pada Kurikulum 2013. Ibriez : Jurnal Kependidikan Dasar Islam Berbasis Sains, 1(1), 1-18. https://doi.org/10.21154/ibriez.v1i1.4

Khairani, C. (2015). Strategi Pembelajaran Paikem (Scrambel) dan Peningkatan Motivasi Belajar Siswa SDN 6 Selebung Ketangga. Palapa: Jurnal Studi Keislaman Dan Ilmu Pendidikan, 3(1), 23-39. https://doi.org/10.36088/palapa.v3i1.750

Kristiantari, R. (2015). Analisis Kesiapan Guru Sekolah Dasar dalam Mengimplementasikan Pembelajaran Tematik Integratif Menyongsong Kurikulum 2013. JPI (Jurnal Pendidikan Indonesia), 3(2), 460470. https://doi.org/10.23887/jpi-undiksha.v3i2.4462

Kurniaman, O., \& Noviana, E. (2017a). Penerapan Kurikulum 2013 Dalam Meningkatkan Keterampilan, Sikap, Dan Pengetahuan. Primary: Jurnal Pendidikan Guru Sekolah Dasar, 6(2), 389. https://doi.org/10.33578/jpfkip.v6i2.4520

Kurniaman, O., \& Noviana, E. (2017b). Penerapan Kurikulum 2013 Dalam Meningkatkan Keterampilan, Sikap, Dan Pengetahuan. Primary: Jurnal Pendidikan Guru Sekolah Dasar, 6(2). https: //doi.org/10.33578/jpfkip.v6i2.4520

Makaborang, Y. (2019). Evaluasi Implementasi Kurikulum 2013 Mata Pelajaran Biologi Di SMA Negeri. Kelola: Jurnal Manajemen Pendidikan, 6(2), 130-145. https://doi.org/10.24246/j.jk.2019.v6.i2.p130-145

Morelent, Y., \& Syofiani. (2018). Pengaruh Penerapan Kurikulum 2013 Terhadap Pembentukan Karakter Siswa Sekolah Dasar Negeri 05 Percobaan Pintu Kabun Bukittinggi. Jurnal Penelitian Bahasa Dan Sastra Indonesia, 1(2), 141-152. https://doi.org/10.22202/jg.2015.v1i2.1234

Mulyadin. (2016). Implementasi Kebijakan Pembelajaran Tematik Terpadu Kurikulum 2013 Di SDN Kauman 1 Malang Dan SD Muhammadiyah 1 Malang. Jurnal Edutama, 3(2), 31-48. https://doi.org/10.30734/jpe.v3i2.35

Pamungkas, A., Subali, B., \& Lunuwih, S. (2017). Implementasi Model Pembelajaran IPA Berbasis Kearifan Lokal untuk Meningkatkan Kreativitas dan Hasil Belajar Siswa. Jurnal Inovasi Pendidikan IPA, 3(2), 118-127. https://doi.org/10.21831/jipi.v3i2.14562

Parida. (2015). Pengaruh Pendidikan Dan Pelatihan, Supervisi, Dan Kompetensi Pedagogik Terhadap Komitmen Profesi Pada Guru SMP Negeri Di Kabupaten Sarolangun Provinsi Jambi. Edukasi Islam Jurnal Pendidikan, 04, 896-905. https://doi.org/10.30868/ei.v4i07.69

Prasetyo, A., Hartini, T., Damayani, A., Mushafanah, Q., \& Zahraini, D. A. (2016). IbM Himpaudi Kecamatan Kaliwungu Kendal Dalam Rangka Penyusunan Perangkat Pembelajaran Kurikulum 2013. E-Dimas: Jurnal Pengabdian Kepada Masyarakat, 7(2), 1 - 8. https://doi.org/10.26877/e-dimas.v7i2.1128

Rahmawati, F., Utami, M., \& Noviati, M. (2014). Pembelajaran Bahasa Indonesia yang Berkarakter, Aktif, dan Menyenangkan di SD Muhammadiyah 10 Surakarta. Profesi Pendidikan Dasar, 1(1), 71-77. https://doi.org/10.23917/ppd.v1i1.943

Resbiantoro, G. (2016). Analisis Pedagogical Content Knowledge (Pck) Terhadap Buku Guru Sd Kurikulum 2013. Scholaria: Jurnal Pendidikan Dan Kebudayaan, 6(3), 153. https://doi.org/10.24246/j.scholaria.2016.v6.i3.p153-162

Sabihi, M. (2019). Penerapan Paikem Gembrot Untuk Menignkatkan Hasil Belajar Sains Di Sekolah Dasar. Jurnal Basicedu, 3(4), 2144-2158. https://doi.org/10.31004/basicedu.v3i4.271 
Safitri, S. R., \& Budhi, W. (2017). Pengaruh Model Pembelajaran Inkuiri Terhadap Hasil Belajar IPA Ditinjau Dari Kemandirian Belajar Siswa. Natural: Jurnal Ilmiah Pendidikan IPA, 4(2), 34-40. https://doi.org/10.30738/natural.v4i2.1852

Shafa. (2014). Karakteristik Proses Pembelajaran Kurikulum 2013. Jurnal Dinamika Ilmu, 14(1), 81-96. https://doi.org/10.21093/di.v14i1.9

Subadi, T., Priyono, K. D., Dahroni, \& Musyiyam, M. (2013). Implementasi Pembelajaran IPS Berbasis Kurikulum 2013 Melalui Lesson Study Di Sekolah Muhammadiyah Kartasura. WARTA, 18(1), 6276. https://doi.org/10.23917/warta.v18i1.1168

Sulthon, S. (2016). Pembelajaran IPA yang Efektif dan Menyenangkan bagi Siswa MI. Elementary, 4(1), 3854. https://doi.org/10.21043/elementary.v4i1.1969

Suparlan. (2017). Implementasi Pendekatan Saintifik Kurikulum 2013 pada Pembelajaran IPA di SD/MI Kelas IV. Fondatia, 1(2), 93-115. https://doi.org/10.36088/fondatia.v1i2.104

Suryaningsih, E. (2016). Upaya Meningkatkan Motivasi Belajar dengan Menerapkan Model Reading Guide Berbasis PAIKEM bagi Peserta Didik di SDN Model Mataram. Jurnal Kependidikan, 2(1). https://doi.org/10.33394/jk.v2i1.428

Susilo, A., Pratiwi, Y., \& Sunoto, S. (2018). Relevansi Nilai Sosial dalam Antologi Puisi Malu Aku Jadi Orang Indonesia Karya Taufik Ismail dengan Muatan Isi Kurikulum 2013. Jurnal Pendidikan: Teori, Penelitian, Dan Pengembangan, 3(1). https://doi.org/10.17977/jptpp.v3i1.10375

Sutrisno. (2015). Penilaian pembelajaran tematik pada kurikulum 2013 di sekolah dasar. Jurnal Sekolah Dasar, 1(1), 12-17. http://journal2.um.ac.id/index.php/sd/article/view/1356

Wahyudin, W. (2018). Optimalisasi Peran Kepala Sekolah dalam Implementasi Kurikulum 2013. Jurnal Kependidikan, 6(2), 249-265. https: //doi.org/10.24090/jk.v6i2.1932

Wahyudin, Wahyudin. (2018). Optimalisasi Peran Kepala Sekolah dalam Implementasi Kurikulum 2013. Jurnal Kependidikan, 6(2), 249-265. https://doi.org/10.24090/jk.v6i2.1932

Wardani, N. K. T. Y. P., Sulastri, M., \& Margunayasa, I. G. (2015). Pengaruh Model Heuristik Vee dengan Peta Pikiran terhadap Hasil Belajar IPA Siswa Kelas V SD. Mimbar PGSD Undiksha, 3(1). https://doi.org/10.23887/jjpgsd.v3i1.5749 